\title{
The decline of a Pinus nigra Arn. reforestation stand on a limestone substrate: the role of nutritional factors examined by means of foliar diagnosis
}

\author{
Enrico Cenni, Filippo Bussotti*, Lorenzo Galeotti \\ Laboratory of Applied and Forest Botany, Department of Plant Biology, \\ University of Florence, Piazzale delle Cascine 28, I 50144 Florence, Italy
}

(Received 6 June 1997; accepted 26 November 1997)

\begin{abstract}
The Austrian black pine reforestation projects on Monte Morello, near the heavily populated metropolitan area of Florence (Italy), have been affected for many years now by a severe decline consisting of widespread crown yellowing. To investigate the causes of this decline foliar diagnosis methods were used to monitor the nutritional status of ten trees, sampling and analysing every year, between 1989 and 1992, the current year needles (c), needles from the previous year $(\mathrm{c}+1)$ and from the year before that $(\mathrm{c}+2)$. The parameters examined were both chemical (nitrogen, sulphur, magnesium, potassium, calcium, manganese, iron and lead) and morphological (needle length, flat projection, dry weight, specific dry weight and water content). The findings show a considerable calcium accumulation as the needles age, accompanied by an increase in dry weight and specific dry weight, as well as a marked antagonism to manganese. The influence of the nearby metropolitan area of Florence is suggested by the accumulation of lead. (C Inra/Elsevier, Paris)
\end{abstract}

afforestation / calcium / iron / leaf senescence / manganese / Pinus nigra subsp. nigra / chlorosis

Résumé - Le dépérissement des reboisements de Pinus nigra Arn. sur substrat calcaire ; le rôle des facteurs nutritionnels étudiés à l'aide du diagnostic foliaire. Les reboisements de pin noir d'Autriche dans le Monte Morello, près de l'importante zone urbaine de Florence (Italie) sont affectés depuis maintenant plusieurs années d'un sévère dépérissement consistant en un jaunissement très fréquent des couronnes. Pour étudier les causes de ce dépérissement, des méthodes d'analyse foliaire ont été utilisées pour suivre l'état nutritionnel de dix arbres échantillonnés et analysés chaque année entre 1989 et 1992, en prenant en compte les aiguilles de l'année (c), les aiguilles de l'année précédente $(c+1)$ et les aiguilles âgées de 2 ans $(c+2)$. Les paramètres étudiés étaient chimiques (azote, soufre, magnésium, potassium, calcium, manganèse, fer, plomb) mor-

\footnotetext{
* Correspondence and reprints

E-mail: fbussotti@cesit 1.unifi.it
} 
phologiques (longueur des aiguilles, surface projetée, poids sec spécifique et teneur en eau). Les résultats montrent une accumulation considérable de calcium avec l'âge des aiguilles accompagnée par un accroissement du poids sec et du poids spécifique, ainsi qu'un antagonisme marqué du manganèse. L'influence de l'agglomération voisine de Florence est suggérée par l'accumulation de plomb. (C) Inra/Elsevier, Paris)

reboisement / calcium / fer / sénescence foliaire / manganèse / Pinus nigra subsp. Nigra / chlorose

\section{INTRODUCTION}

In the first half of this century, several species of conifers were widely used in Italy to reforest areas where the autochthonous forest vegetation normally consists of broadleaved trees. The purpose of these reforestation projects was usually either timber production or hydrogeological protection. Pinus nigra Arn., with all its various subspecies, thanks to its remarkable ecological flexibility, was one of the species most widely used. Today the forest landscape of many Italian regions is characterized by the presence of stretches of conifer forests surrounded by broadleaf woods with no apparent landscape and/or ecological continuity. If we further consider that these species were often planted in environments that were very far from their ecologically ideal setting, and that they are showing all the signs of premature senescence and ecological instability, it is easy to understand how in recent years a lot of discussion has been devoted to the topic, especially the need to allow the sites to gradually revert to a more natural vegetation [24].

In the light of this, our paper examines artificial Pinus nigra stands growing on Monte Morello, in a peri-urban environment near the metropolitan area of Florence (Tuscany, central Italy), and showing severe crown yellowing. The purpose of this study is to assess the vegetational conditions by means of foliar diagnostics $[2,4]$. These artificial stands, planted for protective purposes, today still have an important recreational function, in that they are located in a densely urbanized area (more than 1 million inhabitants). Thus, any conclusions drawn as to their ecological stability or instability could be a valid contribution in guiding the decisions of the city's administrators on the fate and management of these stands.

\section{MATERIALS AND METHODS}

\subsection{Study area}

Monte Morello is a mountain ridge (maximum height: $934 \mathrm{~m}$ a.s.l.) running from $\mathrm{NW}$ to SE, located immediately north-west of the urban area of Florence. The prevailing lithological component is limestone and marl; the forest soils are for the most part shallow, rich in skeleton and scarse in humified organic substances. The mean $\mathrm{pH}$ of the surface layer of the soil $(0-20 \mathrm{~cm})$ is 7.76 ; the $\mathrm{CaCO}_{3}$ content ranges from $10 \%$ in the upper layer $(0-5 \mathrm{~cm}$ under the organic matter layer) to $30 \%$ (at $10-20 \mathrm{~cm}$ deep). The climate is temperate, with hot summers characterized by moderately severe droughts; the mean yearly temperature is about $12^{\circ} \mathrm{C}$, while mean yearly rainfall ranges from $900 \mathrm{~mm}$ at the lower altitudes to 1 100-1 $200 \mathrm{~mm}$ at the higher ones. Monte Morello marks the transition point between a thermophile sub-Mediterranean flora and a mountain flora typical of the Apennines. Most of the spontaneous stands consist of mixed deciduous xerothermal oakwoods, typical of the sub-Mediterranean horizon, with a prevalence of Quercus pubescens Willd. and Fraxinus ornus $\mathrm{L}$. Anthropogenous vegetation is also very widespread, for the most part consisting of conifer reforestation projects, growing mainly at the higher altitudes of the mountain ridge, but also present along the southern slopes of the lower hillsides. These stands are 
made up of conifers, the result of planting programmes [26] begun in 1909 and continued, with diminishing intensity, till the early 1970s. The purpose of all these planting programmes was to provide hydrogeological stability in areas with difficult pedoclimatic conditions which were covered by secondary meadows or by degraded broadleaf woods. Today, the artificial stands cover an area greater than 500 ha. The most widely used species are Austrian pine and laricio pine (Pinus nigra subsp. nigra and Pinus nigra subsp. laricio (Poiret) Maire), cypress (Cupressus sempervirens L.) and silver fir (Abies alba Mill.), with a sporadic presence of other species. These stands are often characterized by poor regeneration, marked susceptibility to adversities and a high degree of inflammability. Moreover, the soil they grow on, despite the satisfactory evolution undergone as compared to the pre-existing situation [3], is still poorly evolved and fairly shallow. Black pines were used also at lower altitudes, and in conditions that are definitely more Mediterranean than the ecological requirements of the species [14].

The reforestation projects on Monte Morello were among the first stands studied in Italy for the decline of black pines caused by unknown agents [5] and the influence of air pollutants was hypothesized. In fact the influence of the metropolitan area is notable primarily in the marked acidification of the precipitations [1, 13] and in the high summertime concentrations of ozone (Italian Botanical Society, unpublished report). Thanks to the limestone matrix of the soil, however, no phenomena of soil acidification have been observed [30].

Moreover, as early as the 1970s, Poggesi [26] was already reporting widespread occurrences of needle yellowing in black pines, ascribed to the poor stand conditions and an insufficient mycorrhizal status. This symptomatology is still evident today.

\subsection{Sampling}

The study examined ten Austrian pines, between 50 and 70 years old, two from each of five stands along the main ridge of the mountain. Needles from the upper third of the crown were sampled from each tree: needles that had sprouted during the sampling year (c, needles that were about 4 months old at the time of sampling), needles from the previous year ( $c+1$, needles aged about 16 months) and from the year before that $(\mathrm{c}+2$, needles aged about 28 months). Samples were collected for four consecutive years, from 1989 to 1992 , always at the end of summer and following the UN-ECE guidelines [28]. Table I illustrates the sampling protocol.

\subsection{Chemical and morphological tests}

Nitrogen, sulphur, calcium, magnesium, potassium, manganese, iron and lead levels were determined. Nitrogen and sulphur levels were measured with a CHNS Element AnaIyzer (Carlo Erba mod. EA 1108). Analytical determination of the remaining elements (total quantities) was carried out after wet digestion in $\mathrm{HNO}_{3}$ (Suprapur Merck) with depositing refrigeration with an atomic absorption spectrophotometer (Varian Spectra AA-20): calcium, iron, potassium, magnesium, manganese, with flame atomization; lead in a graphite oven.

Table I. Sampling protocol and tests performed.

\begin{tabular}{lccc}
\hline Year of gathering & Age of needles & No. of samples & Type of analysis \\
\hline 1989 & $\mathrm{c}$ & 10 & chemical \\
1990 & $\mathrm{c}$ & 10 & chemical and morphological \\
& $\mathrm{c}+1$ & 10 & chemical and morphological \\
1991 & $\mathrm{c}$ & 10 & $\begin{array}{c}\text { chemical and morphological } \\
\text { chemical and morphological } \\
\end{array}$ \\
$\mathrm{c}+\mathrm{I}$ & 10 & chemical and morphological \\
1992 & $\mathrm{c}+2$ & 10 & chemical and morphological \\
& $\mathrm{c}$ & 10 & chemical and morphological \\
& $\mathrm{c}+1$ & 10 & chemical and morphological \\
\hline
\end{tabular}


The following morphological parameters of 100 needles were also assessed: the flat projection (Area), using a Licor LI-3100 area meter; their fresh weight (FW) and, after drying in an oven at $60^{\circ} \mathrm{C}$ till they reached a constant weight, their dry weight (DW). The following parameters were then calculated: water content $(W C=1-(D W / F W) 100)$ and specific dry weight $(S D W=D W /$ Area $)$.

All data are expressed as mean values, standard deviation and correlations; a variance analysis with ANOVA-LSD test and discriminant analysis were further performed. The software used was Statistica Statsoft Inc. and SPSS for Windows 6.0 .

\section{RESULTS}

The data in table II show the yearly variations in the nutritional status and morphology of the needles over the entire period of the study. The variance analysis results (ANOVA-LSD test) show that the values fluctuate considerably, especially the chemical parameters. Table III, on the other hand, reports the chemical and morphological differences between needles of different ages: the variance analysis allows us to establish that the majority of parameters (except needle length and the surface of the flat projection among the morphological parameters, and magnesium concentration among the chemical ones) displays a gradient in correlation to the needle's age: dry weight, specific dry weight and concentrations of calcium, iron and lead all increase their levels as the needles grow older, while the other parameters all diminish.

The correlation between morphological and chemical parameters were calculated separately for the needles of the different ages $(c, c+1, c+2)$ and then globally, for the entire sample, using Spearman's non-parametric $r$ coefficient. The significant correlations which are of the greatest interest within the context of this investigation are described in detail below: they

Table II. Variations in morphological and chemical parameters of $\mathrm{c}$ needles collected at different times $(n=10)$ and comparison with the standards reported in the literature. Mean \pm standard deviation. Letters in boldface indicate the results of the variance analysis (ANOVA-LSD test).

\begin{tabular}{lccccc}
\hline Parameter & Standard & 1989 & 1990 & 1991 & 1992 \\
\hline Morphology & & & & & \\
L (cm) & & & $8.82 \pm 2.44 \mathbf{a}$ & $11.17 \pm 1.78 \mathbf{b}$ & $10,67 \pm 2.17 \mathbf{a}$ \\
Area $\left(\mathrm{cm}^{2}\right)$ & & & $96.7 \pm 30.2 \mathbf{a}$ & $102 \pm 20.9 \mathbf{a}$ & $105 \pm 22.3 \mathbf{a}$ \\
DW $(\mathrm{g})$ & & & $3.10 \pm 0.73 \mathbf{a}$ & $3.93 \pm 0.78 \mathbf{b}$ & $4.04 \pm 0.77 \mathbf{b}$ \\
WC $(\%)$ & & & $60.8 \pm 5.18 \mathbf{a}$ & $63.4 \pm 1.19 \mathbf{a}$ & $59.1 \pm 2.08 \mathbf{b}$ \\
SDW (mg cm $\left.{ }^{-2}\right)$ & & $33.0 \pm 6.18 \mathbf{a}$ & $38.5 \pm 2.68 \mathbf{b}$ & $38.6 \pm 2.86 \mathbf{b}$ \\
& & & & & \\
Chemistry & & & & & \\
$\mathrm{N}(\%)$ & $1.2-1.5$ & $1.37 \pm 0.21 \mathbf{a}$ & $1.29 \pm 0.17 \mathbf{a}$ & $1.13 \pm 0.23 \mathbf{b}$ & $1.25 \pm 0.13 \mathbf{a}$ \\
$\mathrm{S}(\%)$ & $0.12-0.18$ & $0.040 \pm 0.006 \mathbf{a}$ & $0.050 \pm 0.009 \mathbf{b}$ & $0.043 \pm 0.006 \mathbf{a}$ & $0.029 \pm 0.001 \mathbf{c}$ \\
$\mathrm{K}(\%)$ & 0.5 & $1.14 \pm 0.20 \mathbf{a}$ & $0.36 \pm 0.04 \mathbf{b}$ & $0.50 \pm 0.17 \mathbf{c}$ & $0.41 \pm 0.06 \mathbf{b}$ \\
$\mathrm{Ca}(\%)$ & $0.1-0.12$ & $0.88 \pm 0.32 \mathbf{a}$ & $0.179 \pm 0.072 \mathbf{b}$ & $1.271 \pm 0.552 \mathbf{c}$ & $1.902 \pm 1.318 \mathbf{c}$ \\
$\mathrm{Mg}(\%)$ & $0.10-0.14$ & $0.137 \pm 0.030 \mathbf{a}$ & $0.093 \pm 0.028 \mathbf{b}$ & $0.091 \pm 0.016 \mathbf{b}$ & $0.12 \pm 0.024 \mathbf{a}$ \\
$\mathrm{Fe}(\mathrm{ppm})$ & $40-60$ & $36.6 \pm 17.7 \mathbf{a}$ & $48.7 \pm 15.5 \mathbf{b}$ & $30.7 \pm 9.02 \mathbf{a}$ & $23.4 \pm 9.26 \mathbf{c}$ \\
$\mathrm{Mn}(\mathrm{ppm})$ & $>50$ & $34.9 \pm 15.0 \mathbf{a}$ & $78.6 \pm 20.4 \mathbf{b}$ & $31.2 \pm 9.57 \mathbf{a}$ & $33.0 \pm 13.6 \mathbf{a}$ \\
$\mathrm{Pb}(\mathrm{ppm})$ & & $13.3 \pm 2.23 \mathbf{a}$ & $2.38 \pm 0.97 \mathbf{b}$ & $12.30 \pm 4.05 \mathbf{a}$ & $4.10 \pm 1.00 \mathbf{c}$ \\
\hline
\end{tabular}


Table III. Variations in the morphological and chemical parameters of needles of different ages. Mean \pm standard deviation. Letters in boldface indicate the results of the variance analysis (ANOVA-LSD test).

\begin{tabular}{|c|c|c|c|}
\hline Parameter & $\begin{array}{c}\mathrm{c} \\
n=40\end{array}$ & $\begin{array}{c}c+1 \\
n=30\end{array}$ & $\begin{array}{c}c+2 \\
n=20\end{array}$ \\
\hline \multicolumn{4}{|l|}{ Morphology } \\
\hline $\mathrm{L}(\mathrm{cm})$ & $10.2 \pm 2.31 \mathbf{a}$ & $10.5 \pm 2.03 \mathbf{a}$ & $10.8 \pm 1.67 \mathbf{a}$ \\
\hline Area $\left(\mathrm{cm}^{2}\right)$ & $101 \pm 24.2 \mathbf{a}$ & $101 \pm 23.3 \mathbf{a}$ & $104 \pm 20.5 \mathbf{a}$ \\
\hline DW (g) & $3.68 \pm 0.84 \mathbf{a}$ & $4.32 \pm 0.92 \mathbf{b}$ & $4.61 \pm 0.83 \mathbf{b}$ \\
\hline $\mathrm{WC}(\%)$ & $61.1 \pm 3.66 \mathrm{a}$ & $56.9 \pm 3.10 \mathbf{b}$ & $56.1 \pm 3.99 \mathbf{b}$ \\
\hline $\operatorname{SDW}\left(\mathrm{mg} \mathrm{cm}^{-2}\right)$ & $36.7 \pm 4.86 \mathbf{a}$ & $42.9 \pm 3.11 \mathbf{b}$ & $44.4 \pm 3.21 \mathrm{~b}$ \\
\hline \multicolumn{4}{|l|}{ Chemistry } \\
\hline $\mathrm{N}(\%)$ & $1.26 \pm 0.20 \mathrm{a}$ & $1.16 \pm 0.27 \mathbf{a}$ & $0.97 \pm 0.32 \mathbf{b}$ \\
\hline $\mathrm{S}(\%)$ & $0.041 \pm 0.01 \mathbf{a}$ & $0.032 \pm 0.01 \mathbf{b}$ & $0.028 \pm 0.01 \mathbf{b}$ \\
\hline $\mathrm{K}(\%)$ & $0.60 \pm 0.34 \mathbf{a}$ & $0.31 \pm 0.10 \mathbf{b}$ & $0.31 \pm 0.09 \mathbf{b}$ \\
\hline $\mathrm{Ca}(\%)$ & $1.05 \pm 0.95 \mathbf{a}$ & $3.22 \pm 2.87 \mathbf{b}$ & $5.12 \pm 3.42 \mathbf{b}$ \\
\hline $\operatorname{Mg}(\%)$ & $0.11 \pm 0.032 \mathbf{a}$ & $0.11 \pm 0.037 \mathbf{a}$ & $0.096 \pm 0.035 \mathbf{a}$ \\
\hline $\mathrm{Fe}(\mathrm{ppm})$ & $34.9 \pm 15.9 \mathbf{a}$ & $82.0 \pm 37.3 \mathrm{~b}$ & $74 \pm 29.7$ b \\
\hline $\mathrm{Mn}(\mathrm{ppm})$ & $44.4 \pm 24.7 \mathbf{a}$ & $62.6 \pm 48.2 \mathbf{a}$ & $32.9 \pm 18.25 \mathbf{b}$ \\
\hline $\mathrm{Pb}(\mathrm{ppm})$ & $8.04 \pm 5.43 \mathbf{a}$ & $9.75 \pm 6.24 \mathbf{a}$ & $13.5 \pm 7.54 \mathbf{b}$ \\
\hline
\end{tabular}

relate primarily to the levels of calcium, iron and manganese.

\section{1. c needles}

Iron and manganese correlate inversely to calcium (iron-calcium: no. $40, \mathrm{r}=$ $-0.34, P=0.0276$; manganese-calcium: no. $40, r=-0.53, P=0.00041)$ and both elements correlate positively to each other (no. $40, \mathrm{r}=0.59, P=0.00005$ ). These trends are visualized in figures $I$ and 2 . Figure 1 also shows that the calcium-manganese and calcium-iron relations are better expressed by logarithmic-type functions than by linear ones. Considering the dry weight of 100 needles as a parameter of productivity, one can observe that it correlates inversely with both iron (no. $30, \mathrm{r}=-0.51, P=0.0036$ ) and manganese (no. $30, \mathrm{r}=-0.45, P=0.0105$ ).

\section{2. $c+1$ and $c+2$ needles}

In $c+1$ needles, and even more so in $c+2$ needles, most of the correlations found in $c$ needles are no longer observable. Yet, in $\mathrm{c}+\mathrm{l}$ needles the iron-manganese-calcium group behaves in a very similar manner to how it behaves in c needles, while these correlations are no longer there in c+2 needles.

\subsection{Needles of all ages}

In order to have an equal representation of all ages examined, only the data from the samplings of 1991 and 1992 were processed and included in the calculations (i.e. the values for 60 cases, distributed as follows: $20 \mathrm{c}$ needles, $20 \mathrm{c}+1$ and $20 \mathrm{c}+2$ ). The correlations described above hold true for the entire sample, except for the correlation between calcium and iron which is no longer visible. In this context it is inter- 


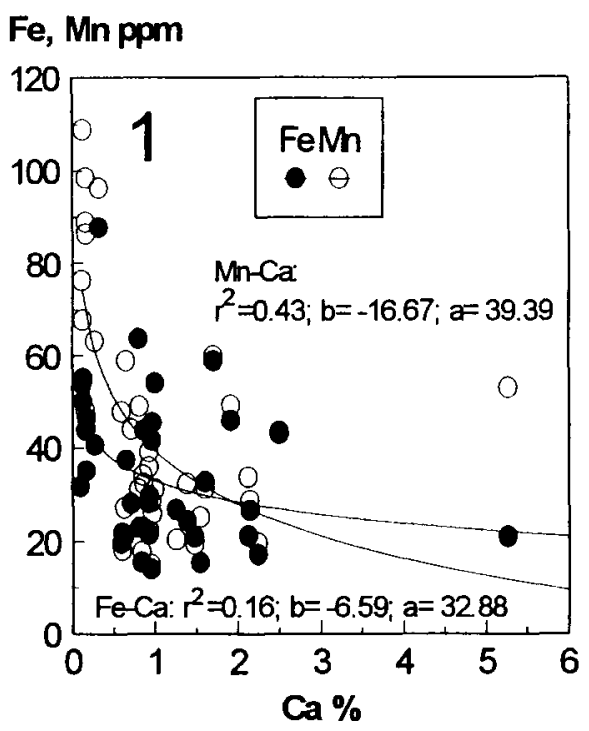

Figure 1. Logarithmic correlations, calcium-iron and calcium-manganese, in c needles; $n=40$.

esting to note that some elements frequently accompany the ageing processes which are expressed through a change in specific dry weight (it increases) and/or water content (it decreases). Calcium correlates strongly with both these parameters (no. 60, Ca-WC: $\mathrm{r}=-0.58, P<0.001$; $\mathrm{Ca}-$ SDW: $\mathrm{r}=0.38, P=0.0062$ ), whereas iron correlates only with specific dry weight (no. 60, $\mathrm{r}=0.37, P=0.0092$ ). These findings are also reported in figures 3 and 4 , where we can observe that these correlations are expressed better by exponentialtype functions.

Lastly, a discriminant analysis was performed in order to ascertain the relative weight of each variable considered in the differentiation of the three needle ages. In order to select those variables that are important in distinguishing the groups, a stepwise selection algorithm was used: the results are summarized in table $I V$. There are three elements capable of distinguish-

\section{Mn ppm}

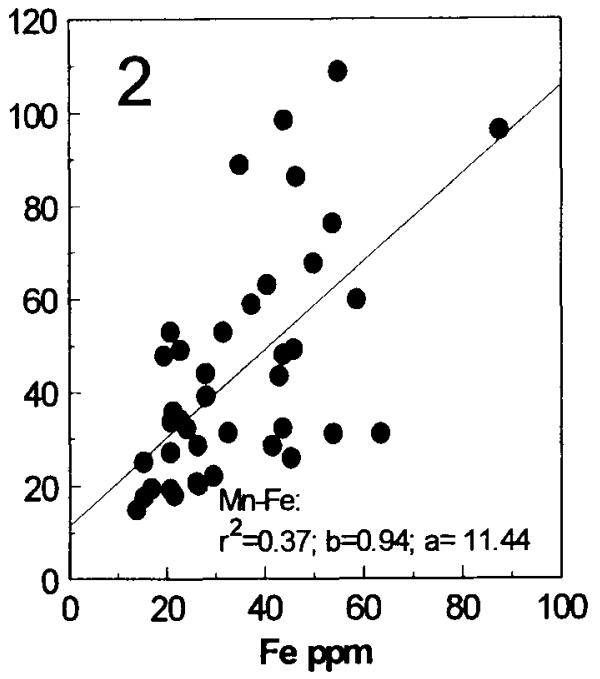

Figure 2. Linear type correlation between iron and manganese in c needles; $n=40$.

ing between the different needle ages: calcium, iron and manganese. Calcium (which has the lowest Wilks lambda) contributes more than any other variable to the total discrimination of the three groups; manganese and iron follow in decreasing order. Of the two extracted canonic functions only the first is significant $(98 \%$ of the discriminating power is provided by this function): it distinguishes between group 1 (c needles) and group 3 (c+2 needles), where the difference between the mean values is greatest. Of the three variables, iron is the one that contributes most to the discrimination specified by this function.

\section{DISCUSSION}

The findings on the nutritional status of Austrian pine needles, if compared to the nutrional standards of this species or 


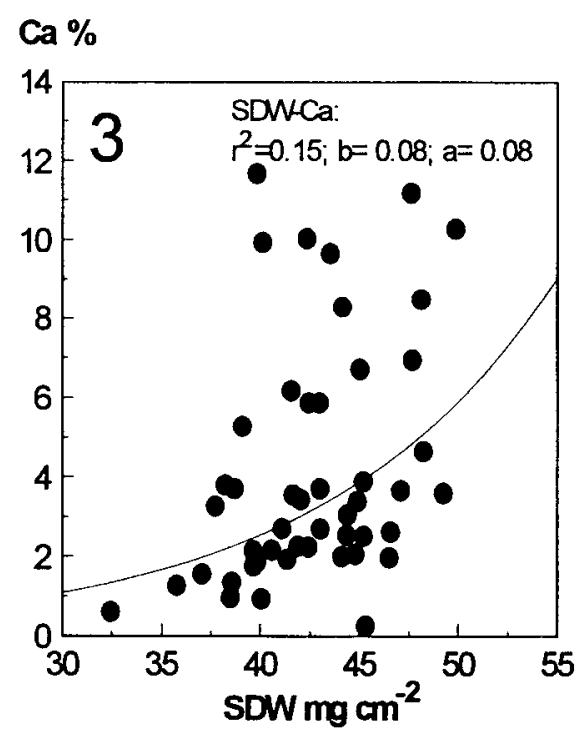

Figure 3. Exponential-type correlation between specific dry weight (SDW) and calcium, in a sample of needles of all ages; $n=60$.
Fe, Mn ppm

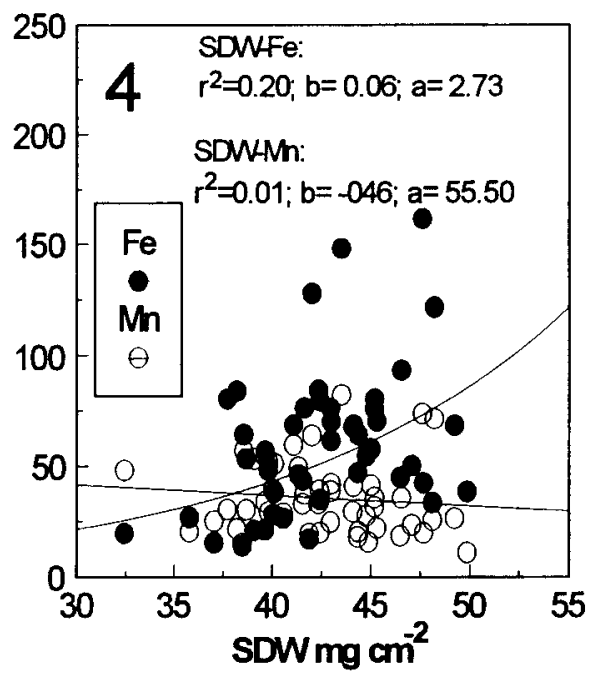

Figure 4. Exponential-type correlations between specific dry weight (SDW) and iron, and between specific dry weight and manganese, in a sample of needles of all ages; $n=$ 60

Table IV. Results of the stepwise selection and standardized coefficient of the canonic discriminant functions, in relation to the needle's age.

\begin{tabular}{lccccc}
\hline Variable & Tolerance & F to remove & Wilk's Lambda & Func. 1 & Func. 2 \\
\hline $\mathrm{Ca}$ & 0.970 & 4.639 & 0.458 & -1.598 & -0.065 \\
$\mathrm{Fe}$ & 0.550 & 21.348 & 0.713 & 0.446 & 0.216 \\
$\mathrm{Mn}$ & 0.539 & 7.535 & 0.502 & 1.261 & -0.182 \\
\hline
\end{tabular}

similar species (cf. [2, 4, 19, 29]), mainly show a considerable accumulation of calcium that is more evident in $c+1$ and $c+2$ needles. The increase in calcium in the older needles is a well-known physiological phenomenon [11], although in this case it has undoubtedly been accentuated by the geological matrix. According to Bergmann [2] iron and manganese also accumulate in the older needles, but in our findings this can only be observed in the iron levels, and these elements (iron in c needles, but mainly manganese) are clearly deficient.

Sulphur levels are also very low, but the concentration of this element is comparable to the mean values measured in Italy in a number of forest species [7, 23]; the low and diminishing levels of sulphur allow us to rule out any significant impact of $\mathrm{SO}_{2}$ from the surrounding urbanized areas. Rather, the impact of the metropoli- 
tan area nearby is detectable with the high lead concentration levels.

Magnesium is constantly maintained at optimum levels, in accordance with other observations of this element on limestone soils [2], whereas on acid soils there are often incidences of chlorosis due to magnesium deficiency [18]. Potassium concentrations are close to ideal levels in $c$ needles, but they decrease considerably in older needles. Low levels of potassium are usual in trees growing on limestone soils [2]. An analogous behaviour of potassium concentrations has been described by Magalotti et al. [23] in Pinus pinea L. needles growing on terrain characterized by sodium alkalinity.

The decrease in concentration of some elements is a normal feature related to the ageing process [20]. According to Schulze [27] conifers subjected to stress translocate part of their nutritional elements from the older needles to the younger ones.

The morphological changes observed in this study (increased specific dry weight and reduced water content), although they have already been observed in other species before, are consistent with processes of stress and/or ageing [7,8].

Potassium, iron and manganese deficiencies have been reported as inducing needle chlorosis in trees growing mainly on limestone soils $[2,17,21,27]$. On limestone soil, in fact, calcium exerts an antagonistic action towards these elements, especially against iron and manganese [2]. Sulphur deficiencies can also be considered as a factor predisposing the tree to chlorosis $[10,21]$.

Especially noteworthy is the wide range of fluctuations between one year and the next. In the 1990 sampling a higher level of manganese and iron was detected, but no evaluable changes in crown conditions were observed.

An analysis of the correlations between the parameters examined suggests that cal- cium plays a decisive role, influencing both the absorption and metabolism of several microelements (iron and - even more so-manganese) and the processes of foliar ageing. As the needle ages, calcium probably accumulates in the form of oxalate crystals both inside the vacuoles and in the apoplast, as well as in extracellular sites $[11,12]$. These processes probably also cause the increase in dry weight. The findings of this study allow us to conclude that calcium can be considered as 'the independent ecological variable' which exercises a dominant role over all the chemical and morphological parameters.

It is interesting to observe the different behaviour patterns of calcium, manganese and iron in relation to the senescence process. The needle's ageing may be expressed by means of an increase in specific dry weight. While calcium and iron display an exponential-type positive correlation with specific dry weight (figures 3 and 4), this does not occur with manganese (figure 4). These findings suggest that calcium exerts a greater antagonistic action on manganese than on iron. The former no longer cumulates in the needles after the first year of their life, whereas the uptake and storage of the latter is continuous.

\section{CONCLUSIONS}

The findings described above suggest that the poor conditions of the Pinus nigra reforestation site on Monte Morello can be related to nutritional deficiencies and inbalances, despite the fact that this species is normally assumed to be sparing and tolerant to calcium and environmental stress factors. In fact in the study stand the trees are growing in extreme conditions, on a rocky limestone soil outside their ideal climate range. Our findings show that there is a considerable antagonism 
between calcium and manganese, and that a manganese deficiency (combined with a less marked iron deficiency) can cause extensive leaf yellowing, a symptom described as "limestone chlorosis' (cf. [16]). The low levels of potassium and sulphur may contribute to chlorosis. Hilbrunner and Fluickiger [17] have reported on several Abies alba Mill. reforestation stands with marked instances of chlorosis due to manganese deficiency. In such conditions needle chlorosis induced by manganese deficiency is frequently more pronounced in current-year needles than in older needles.

The fact that yearly fluctuations in the mineral content of the needles are not immediately reflected by significant changes in crown conditions suggests that the relationships among the elements are complex and their balance plays a fundamental role [27], as well as the relationships among elements, other environmental factors and the physiological functions of the trees.

The Monte Morello forest is very close to a highly urbanized environment and is affected by pollutants originating from that area (acid rains and ozone): that may also be important, but we still do not know exactly how this factor interacts with the edaphic and nutritional stresses described above.

From a more general point of view, this study offers a further contribution to the issues relating to the decline of artificial coniferous reforestation sites (cf. $[6,9,15$, $17,22,25]$ ), especially when the ecological compatibility between species and stand is not ideal. It is highly likely that this type of difficulty will increase in the future, owing to possible climate changes. Thus, the study of naturalistic criteria to be followed in reforestation projects becomes a necessity not merely from the aesthetic and landscape-planning point of view, but also as a guarantee of the ecological stability of the plantations and, as a conse- quence, of their ability to perform the functions they were designed for.

\section{ACKNOWLEDGEMENTS}

This study was carried out thanks to a contribution by the Regione Toscana (Study on forest damage). The Authors wish to thank $\mathrm{Mr}$ Giulio Boschi for the sampling; Agrochimica Pisana for the chemical analyses and Dr Piero Bruschi for assistance with the statistics.

\section{REFERENCES}

11] Bellandi S., Cenni E., Gellini R., Ferretti M., Pantani F., Veneziani M., Chimismo delle precipitazioni in una foresta periurbana dell area fiorentina, Acqua Aria (10) (1993) 1095-1100.

[2] Bergmann W., Nutritional Disorder of Plants, G. Fisher Verlag, Jena, 1992.

[3] Bernetti G., Osservazioni sull'influenza della vegetazione sul terreno nei rimboschimenti di Monte Morello, in: Atti del congresso nazionale sui rimboschimenti e sulla ricostituzione dei boschi degradati, vol. II, Firenze, 1961, pp. 99-110.

14| Bonneau M., La diagnostic foliaire, Rev. For. Fr. 40 (1988) 19-28.

[5] Bottacci A., Brogi L., Bussotti F., Cenni E., Clauser F., Ferretti M., Gellini R., Grossoni P., Schiff S., Inquinamento ambientale e deperimento del bosco in Toscana, Regione Toscana, Società Botanica Italiana, Firenze, 1988.

[6] Bussotti F., Ferretti M., Cenni E., Gellini R., Clauser F., Grossoni P., Barbolani E., New type forest damage to mediterranean vegetation in Southern Sardinian forests (Italy), Eur. J. For. Path. 21 (1991) 290-300.

[7] Bussotti F., Ferretti M., Cenni E., Grossoni P., Monitoring of mineral nutrients and trace elements in broadleaves: a survey in Tuscany, in: Nilsson L.O., Hüttl R.F., Johansson U.T., Mathy P. (Eds.), Nutrient Cycling in Forest Ecosystems, Proc. CEC/IUFRO Symposyum,. Ecosystem Res. Rep., Brussels 21 (1995) 99-106.

[8] Bussotti F., Grossoni P., Bottacci A., Sclerophylly in beech (Fagus sylvatica L.) trees: its relationship with crown transparency, nutritional status and summer drought, Forestry 70 (1997) 267-271.

[9] Cantiani P., Indagine sui danni da gelo nelle pinete dell'alto litorale adriatico, It. For. Mont. I (1994) 54-70. 
[10] Ende H.P., Hüttl R.F., Insufficient sulfur nutrition of yellowed spruce and beech in the Southern Black Forest, Phyton 32 (1992) 47-50.

[11] Fink S., The micromorphological distribution of bound calcium in needles of Norway spruce (Picea abies (L.) Karst.), New Phytol. 119 (1991) 33-40.

[12] Fink S., Unusual patterns in the distribution of calcium oxalate in spruce needles and their possible relationships to the impact of pollutants, New Phytol. 119 (1991) 41-51.

[13] Galeotti L., Bellandi S., Cenni E., Pantani F., Monitoraggio delle deposizioni atmosferiche nel complesso forestale periurbano di Monte Morello, Acqua Aria (1997) in press.

[14] Gambi G., Il pino nero, pianta della bonifica montana, Ann. Ist. Sper. Selvic. 14 (1983) $5-43$.

[15] Guyon J.P., Dépérissement du pin maritime (Pinus pinaster Ait.) en Vendée. Les causes écologiques, Ann. Sci. For. 48 (1991) 333-346.

[16] Hartmann G., Nienhaus F., Butin H., Farbatlas Waldschäden, Eugen Ulmer GmbH \& Co, Stuttgard, 1988.

[17] Hiltbrunner E., Flückiger W., Manganese deficiency of silver fir trees (Abies alba) at a reforested site in the Jura mountains, Switzerland: aspects of cause and effect, Tree Physiol. 16 (1996) 963-975.

[18] Hüttl R.F., Mg-deficiency - A 'new' phenomenon in declining forest - Symptoms and effects, causes, recuperation, in: Hüttl R.F., Müller-Dombois D. (Eds.), Forest Decline in the Atlantic and Pacific Regions, Springer Verlag, Berlin, 1993, pp. 97-114.

[19] Kabata-Pendias A., Pendias H., Trace Elements in Soil and Plants, CRC Press, London, 1984.

[20] Kramer P.J., Kozlowski T.T., Physiology of Woody Plants, Academic Press, New York, 1979.

[21] Le Tacon F., Miller C., Influence de conditions de la nutrition minérale sur la croissance de l'épicea commune sur les plateaux cal- caires de l'est de la France, Ann. Sci. For. 27 (1970) 335-355.

[22] Le Tacon F., Bonneau M., Gelpe J., Boisseau T., Baradat P., Le dépérissement du pin maritime dans les Landes de Gascogne à la suite des introductions de graines d'origine ibérique et des grands froids des année 1962-63 et 1985, Rev. For. Fr. 46 (5) (1994) 474-484

[23] Magalotti M., Bussotti F., Grossoni P., Tentoni P., Arcangeli A., Effetti di inquinanti atmosferici e stress ambientali in Pinus pinea L. nella pineta di San Vitale, Ravenna, Acqua Aria 1 (1997) 63-68.

[24] Nocentini S., La rinaturalizzazione dei rimboschimenti. Una prova su pino nero e laricio nel complesso di Monte Morello, It. For. Mont. 4 (1995) 425-435

[25] Padula M., Ricerche sulle condizioni ecologiche dei boschi di San Vitale e di Classe (Ravenna) ai fini del loro miglioramento colturale, con saggi di esame degli apparati radicali di Pinus e Quercus, Ann. Acc. It. Sci. For. 17 (1968) 173-246.

[26] Poggesi A., L'opera di rimboschimento sui colli alti fiorentini. Collana di studi sui problemi urbanistici del territorio fiorentino, Provincia di Firenze. Firenze, no. 4, 1976.

[27] Schulze E.D. Air pollution and forest decline in a spruce (Picea abies) forest, Science 244 (1989) 776-783.

[28] UN-ECE, Manual on methodologies and criteria for harmonized sampling, assessment, monitoring and analysis of the effects on air pollution on forests (First draft: 1986) Programme Coordinating Centres Hamburg and Prague, 1994

[29] Van den Burg J., Voorlopige criteria voor de beoordeling van de minerale-voedungstoestand van naaldboomsoorten op basis van de onderzoek in de bos en landschapsbouw, De Dorschkamp, Wageningen, 1988.

[30] Venanzoni R., Werner W., Condizioni chimiche del suolo in alcune foreste toscane in relazione all' acidificazione e al contenuto di metalli pesanti, in: Inquinamento atmosferico e declino del bosco, Società Botanica Italiana, Firenze, 1991, pp. 45-54. 